OPEN ACCESS

Edited by:

Taohai Li,

Xiangtan University, China

Reviewed by:

Edison Pecoraro,

Universidade Estadual Paulista Júlio de Mesquita Filho (UNESP), Brazil

Dayong Cai,

Yanshan University, China

*Correspondence:

Jiu-Ba Wen

wenjiuba12@163.com

Specialty section: This article was submitted to Inorganic Chemistry, a section of the journal

Frontiers in Chemistry

Received: 19 January 2018 Accepted: 06 March 2018

Published: 20 March 2018

Citation:

Yao H, Wen J-B, Xiong Y, Lu Y and Huttula M (2018) Microstructure

Evolution in Mg-Zn-Zr-Gd

Biodegradable Alloy: The Decisive

Bridge Between Extrusion

Temperature and Performance.

Front. Chem. 6:71.

doi: 10.3389/fchem.2018.00071

\section{Microstructure Evolution in Mg-Zn-Zr-Gd Biodegradable Alloy: The Decisive Bridge Between Extrusion Temperature and Performance}

\author{
Huai Yao ${ }^{1,2}$, Jiu-Ba Wen ${ }^{1,2 *}$, Yi Xiong ${ }^{1,2}$, Yan Lu ${ }^{1,2}$ and Marko Huttula ${ }^{3}$ \\ ${ }^{1}$ School of Materials Science and Engineering, Henan University of Science and Technology, Luoyang Henan, China, \\ ${ }^{2}$ Collaborative Innovation Center of Nonferrous Metals of Henan Province, Luoyang Henan, China, ${ }^{3}$ Nano and Molecular \\ Systems Research Unit, University of Oulu, Oulu, Finland
}

Being a biocompatible metal with similar mechanical properties as bones, magnesium bears both biodegradability suitable for bone substitution and chemical reactivity detrimental in bio-ambiences. To benefit its biomaterial applications, we developed Mg-2.0Zn-0.5Zr-3.0Gd (wt\%) alloy through hot extrusion and tailored its biodegradability by just varying the extrusion temperatures during alloy preparations. The as-cast alloy is composed of the $\alpha-M g$ matrix, a network of the fish-bone shaped and ellipsoidal $(\mathrm{Mg}, \mathrm{Zn})_{3} \mathrm{Gd}$ phase, and a lamellar long period stacking ordered phase. Surface content of dynamically recrystallized (DRXed) and large deformed grains increases within $330-350^{\circ} \mathrm{C}$ of the extrusion temperature, and decreases within $350-370^{\circ} \mathrm{C}$. Sample second phase contains the $(\mathrm{Mg}, \mathrm{Zn})_{3} \mathrm{Gd}$ nano-rods parallel to the extrusion direction, and $\mathrm{Mg}_{2} Z \mathrm{n}_{11}$ nanoprecipitation when temperature tuned above $350^{\circ} \mathrm{C}$. Refining microstructures leads to different anticorrosive ability of the alloys as given by immersion and electrochemical corrosion tests in the simulated body fluids. The sample extruded at $350^{\circ} \mathrm{C}$ owns the best anticorrosive ability thanks to structural impacts where large DRXed portions and uniform nanosized grains reduce chemical potentials among composites, and passivate the extruded surfaces. Besides materials applications, the in vitro mechanism revealed here is hoped to inspire similar researches in biometal developments.

Keywords: magnesium alloy, microstructure, dynamic recrystallization, extrusion, corrosion

\section{INTRODUCTION}

The magnesium $(\mathrm{Mg})$ is an essential element for human metabolism where excess amount of the element is harmlessly excreted in urine (Hermawan et al., 2010; Bakhsheshi-Rad et al., 2014; Chen et al., 2014). The non-toxic metal has similar mechanical properties as bones in stress release (Nagels et al., 2003), enabling its potentials to help bone recovery after implantation (Staiger et al., 2006). To extend its usability, the Mg has further been alloyed with different metals and biodegradable implants have been reached (Witte et al., 2006; Witte, 2010; Jafari et al., 2015). Recent investigations further show that the stabilities and durability of the metal and its alloys can be 
switched in at different ambiences, provided dedicated materials engineering is performed for the structural and compositional treatments (Jamesh et al., 2014; Mareci et al., 2016).

Despite the biocompatibility and mechanical uniqueness, the $\mathrm{Mg}$ and its alloys suffer from robust chemical reactivity in aqueous environment where hydrogen is released following $\mathrm{Mg}$ and $\mathrm{H}_{2} \mathrm{O}$ reaction. This rapid corrosion rate results in loss of mechanical strength of the implants before accomplishing their purposes (Wang et al., 2012; Ding et al., 2014). Alloying it with proper metals may enhance its anticorrosive performances. For instance, $\mathrm{Zn}$ can transform impurities, such as $\mathrm{Fe}$ and $\mathrm{Ni}$, into harmless intermetallic compounds and improve the corrosion resistance of $\mathrm{Mg}$ alloys at a content below 5wt.\% (Rosalbino et al., 2010). Though with a relatively low solubility in the $\mathrm{Mg}$ matrix, small amount of $\mathrm{Zr}$ addition can substantially improve the corrosion performances of $\mathrm{Mg}$ alloys ( $\mathrm{Gu}$ et al., 2011). Besides improving mechanical properties (Zhang et al., 2012a), introduction of rare earth elements (REE) into magnesium alloys is also an effective way to enhance corrosion resistance of the magnesium alloys (Song and StJohn, 2002; Gui et al., 2016). Similar strengthening effects can also be achieved by using the Gd as an alloy metal. Research evidences also proved that many REEs are anti-carcinogenic (Dai et al., 2002; Feyerabend et al., 2010). The Gd also possesses the property, and can diminish the amount of cancer cells in the studies (Magda and Miller, 2006; Kostova et al., 2007). Unfortunately, free $\mathrm{Gd}^{3+}$ ion is toxic. Though it can be excreted slowly from human body through metabolism, the accumulation of excessive $\mathrm{Gd}^{3+}$ will induce apoptosis of cells in a short term. Thus, it is necessary to lower the degradation rate of the Gd element to the median lethal dose level (LD50) in the body to ensure the biosafety (Ersoy and Rybicki, 2007). Combining the $\mathrm{Zn}, \mathrm{Zr}$, and REs to the Mg matrix, the Mg-Zn$\mathrm{Zr}-\mathrm{X}(\mathrm{X}=\mathrm{RE})$ quaternary alloys have further been developed. While mechanical strengths have been explored, corrosion tests were performed through hydrogen evolution experiment (Zhang et al., 2012b). Besides the rather complicated synthesis, it is still unclear for the alloy performances and preparation conditions influences on the performances in bio-ambiences.

In this work, we employed hot extrusion route to prepare the Mg-2.0Zn-0.5Zr-3.0Gd (wt\%) biometallic alloys, and studied extrusion temperature impacts on their microstructures and anticorrosive performances in the simulated body fluid (SBF). Benefiting from the hot preparation route at the optimized temperature, dynamic recrystallization (DRX) leads to grain refinements of the alloys. Consequentially, mechanical deformations are enlarged, and the alloys are more resistant in simulated bio-ambiences. The in vitro origin for materials functionality improvements is also proposed.

\section{EXPERIMENTAL PROCEDURE}

Alloy ingot with an actual composition of Mg-2.0Zn-0.5Zr-3.0Gd alloy (wt\%) was melted from high purity $\mathrm{Mg}$ (purity $\geq 99.93 \%$ ) and $\mathrm{Zn}$ (purity $\geq 99.93 \%$ ) ingots. The $\mathrm{Mg}-25 \mathrm{Zr}(\mathrm{wt} \%)$ and $\mathrm{Mg}$ $20 \mathrm{Gd}(\mathrm{wt} \%)$ master alloys were processed under the protective $\mathrm{CO}_{2}+1 \% \mathrm{SF}_{6}$ gas mixture in order to prevent burning of the $\mathrm{Mg}$ in an electronic induction furnace. The equivalent amount of alloy was added when the temperature reached about $730^{\circ} \mathrm{C}$. The melt alloys were further held at $730{ }^{\circ} \mathrm{C}$ for $\sim 20 \mathrm{~min}$ and then poured into a preheated mild steel mold of $160 \times 45 \times 100 \mathrm{~mm}$ in size. As schematic illustration of the extrusion and extruded bars are shown in Figure 1. The cast ingots were machined into blocks with a size of $\Phi 50 \times 35 \mathrm{~mm}$ for extrusion. The cylindrical ingots were extruded at $330,340,350,360$, and $370^{\circ} \mathrm{C}$, and the temperature was measured by a pyrometer infrared thermometer (DIAS, Germany). They are labeled as E330, E340, E350, E360, E370, respectively. Then the cylindrical ingots were extruded into rods with a diameter of $18 \mathrm{~mm}$, an extrusion ratio of $\sim 8$ at a speed of $5 \mathrm{~mm} / \mathrm{s}$. The extruded rods were naturally cooled to room temperature, and annealed $4 \mathrm{~h}$ at $200^{\circ} \mathrm{C}$ afterwards.

The specimens for microstructure observations were cut parallel to the extrusion direction (ED) and mechanically polished. Afterwards, they were etched with the $0.19 \mathrm{~mol} / \mathrm{L}$ picric acid solutions which is obtained by dissolving $5 \mathrm{~g}$ picric acid in $5 \mathrm{~mL}$ acetic acid, and successively mixed with $100 \mathrm{~mL}$ absolute ethyl alcohol and $10 \mathrm{~mL}$ distilled water. The microstructure of the specimens at different conditions was observed using optical microscopy (OLYMPUS) and scanning electronic microscopy (SEM, JSM-5610LV) in back-scattered electron (BSE) mode. By counting the characteristic X-ray emissions through the energy dispersive spectroscopy (EDS), the SEM can further make element identification locally. X-ray diffraction (XRD) experiments were carried out using the D8 ADVANCE X-ray diffractometer. The tube voltage and current were $35 \mathrm{kV}$ and $40 \mathrm{~mA}$, respectively. The scan rate was $0.02^{\circ} / \mathrm{s}$ with $1 \mathrm{~s}$ per step. The detailed microstructure of the extruded samples was examined using transmission electron microscopy (TEM, JEM2010) operated at $200 \mathrm{kV}$. The TEM samples were machined by wire-cutting the rods parallel to ED, and then treated by fluid jet polishing under the $97 \%$ ethyl alcohol and 3\% perchloric acid mixture. Finally, they were iron milled using the twin gun precision ion polishing system (Gatan, model 691).

Anticorrosive performances of the alloys were carried out in SBF which has chemical composites and concentrations as tabulated in Table 1 (Jeong and Kim, 2014). Evaluations of anticorrosion were performed through two experiment sequences of immersion corrosion test and electrochemical

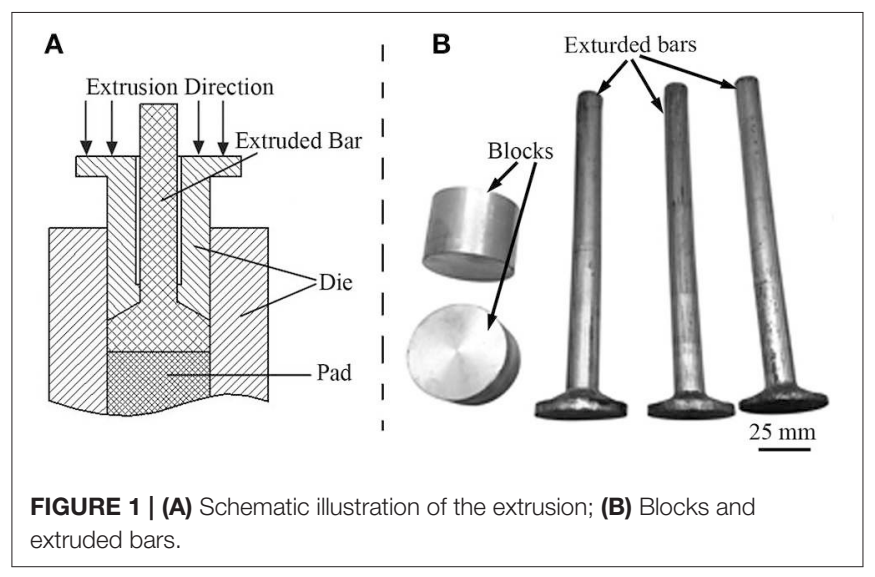


TABLE 1 | Composition of SBF solution.

\begin{tabular}{lc}
\hline Component & Concentration/(g. $\left.\mathbf{L}^{-\mathbf{1}}\right)$ \\
\hline $\mathrm{NaCl}$ & 8.00 \\
$\mathrm{CaCl}_{2}$ & 0.14 \\
$\mathrm{KCl}$ & 0.40 \\
$\mathrm{NaHCO}_{3}$ & 0.35 \\
$\mathrm{MgCl}_{2} \cdot 6 \mathrm{H}_{2} \mathrm{O}$ & 0.10 \\
$\mathrm{GlucOSe}$ & 1.00 \\
$\mathrm{Na}_{2} \mathrm{HPO}_{4} \cdot 12 \mathrm{H}_{2} \mathrm{O}$ & 0.06 \\
$\mathrm{KH}_{2} \mathrm{PO}_{4}$ & 0.06 \\
$\mathrm{MgSO}_{4} \cdot 7 \mathrm{H}_{2} \mathrm{O}$ & 0.06 \\
\hline
\end{tabular}

corrosion test. In the first one, samples with a diameter of $18 \mathrm{~mm}$ and a thickness of $5 \mathrm{~mm}$ were immersed in $180 \mathrm{~mL}$ solutions and the temperature was maintained at $37{ }^{\circ} \mathrm{C}$ under a water bath. The immersion lasted $120 \mathrm{~h}$ during which the SBF was renewed every $8 \mathrm{~h}$ in order to keep a relative stable $\mathrm{pH}$ value. An electrochemical workstation (Autolab PGSTAT128N) was employed in the electrochemical test, and a three-electrode configuration was adopted. The alloy sample $(\Phi 11.3 \times 10 \mathrm{~mm})$ was used as working electrode, a saturated calomel electrode as reference electrode, and a graphite sheet as counter electrode. The working electrodes were connected to a copper wire and then embedded in the epoxy resin. The mounted samples were mechanically polished and exposed a surface area of $1 \mathrm{~cm}^{2}$. Potentiodynamic polarization testing was performed at a scanning rate of $1 \mathrm{mVs}^{-1}$ from $-0.25 \mathrm{~V}$ in the cathodic direction to $+0.4 \mathrm{~V}$ in the anodic direction based on the open circuit potential.

\section{RESULTS AND DISCUSSION}

\section{Microstructure and Phase Analysis of As-Cast Alloys}

Microstructures of the as-cast alloys were firstly alloyed. As depicted in Figure 2, sharp peaks in the XRD pattern are well indexed to $\alpha-\mathrm{Mg}$ matrix (JCPDS89-5003) and ( $\mathrm{Mg}, \mathrm{Zn})_{3} \mathrm{Gd}$ (JCPDS 65-0040) (Zhang et al., 2016). No other peaks can be observed in the XRD, indicating the purity of the as-prepared samples. Figure $\mathbf{3 A}$ shows the SEM image of the as-cast $\mathrm{Mg}$ 2.0Zn-0.5Zr-3.0Gd alloy. The black $\alpha-\mathrm{Mg}$ matrix is decorated with a network of the fish-bone shaped (marked as "A") and ellipsoidal eutectic compounds in Figure 3A. In contrast to these compounds at grain boundaries, the small ellipsoidal shaped eutectic phases (marked as "B") are distributed across the interior of the grains. The EDS analysis of the fish-bones shows the existences of characteristic lines from only $\mathrm{Mg}, \mathrm{Zn}$, and Gd in Figure 3B. The ellipsoidal and fish-bone shaped eutectic compounds have similar element composition. These are consistent with the XRD results, where the phase composition in the as-cast alloy is identified as $\alpha-\mathrm{Mg}$ and $(\mathrm{Mg}, \mathrm{Zn})_{3} \mathrm{Gd}$ phases.

Figures 4A,B shows the TEM bright-field (BF) image of the fish-bone shaped eutectic phase at the grain boundary in the as-cast $\mathrm{Mg}-2.0 \mathrm{Zn}-0.5 \mathrm{Zr}-3.0 \mathrm{Gd}$ alloy, and its corresponding

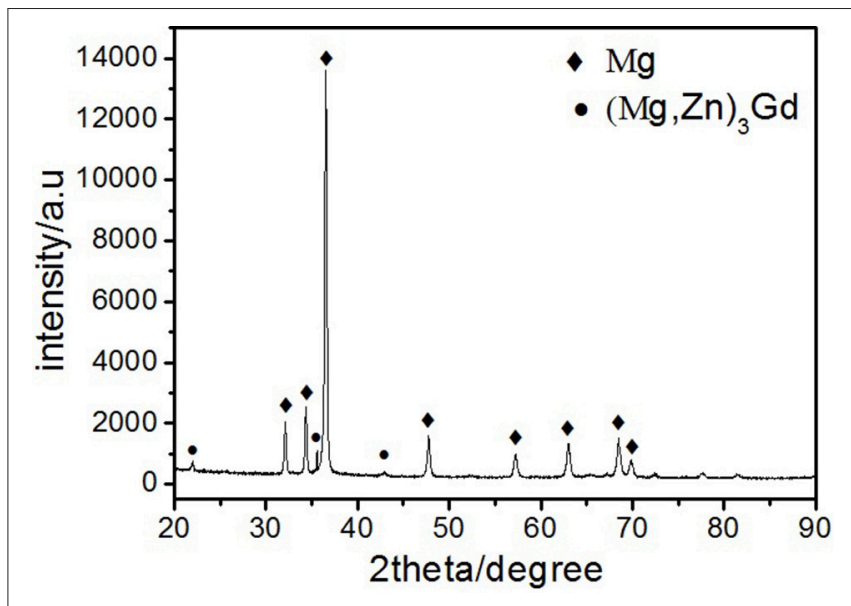

FIGURE 2 | XRD patterns of the as-cast Mg-2.0Zn-0.5Zr-3.0Gd alloy.

selected area electron diffraction (SAED) pattern along the [112] direction. According to the SAED pattern, the phase has facecentered cubic (fcc) structure with a lattice constant of $0.729 \mathrm{~nm}$. Thus, this phase was identified as the $\mathrm{Mg}_{3} \mathrm{Gd}$ phase. However, the EDS results (Figure 3B) reveal the existence of a small quantity of $\mathrm{Zn}$, similar to results given by Srinivasan (Srinivasan et al., 2014). It can be ascribed to solid solution based on the $\mathrm{Mg}_{3} \mathrm{Gd}$, and expressed as (Mg, $\mathrm{Zn})_{3} \mathrm{Gd}$. Moreover, the $\mathrm{Zn}$ and $\mathrm{Gd}$ content variations lead to small changes in the lattice parameters of the (Mg, Zn) ${ }_{3} \mathrm{Gd}$ phases (Xu et al., 2013). The Zn and Mg contents in the $(\mathrm{Mg}, \mathrm{Zn})_{3} \mathrm{Gd}$ differ from the original values at the sample location in the as-cast $\mathrm{Mg}-2.0 \mathrm{Zn}-0.5 \mathrm{Zr}-3.0 \mathrm{Gd}$ alloy. The lattice parameter of the $(\mathrm{Mg}, \mathrm{Zn})_{3} \mathrm{Gd}$ phases significantly decrease with the $\mathrm{Zn} / \mathrm{Mg}$ ratio in the $(\mathrm{Mg}, \mathrm{Zn})_{3} \mathrm{Gd}$.

Figures 4C,D show the BF images of the fine lamella longperiod stacking ordered (LPSO) phase in the matrix, and corresponding SAED pattern recorded along the $[2 \overline{110}]_{\alpha-M g}$ direction. Located at the positions of $n / 7$, where $n$ is an integer of the $(0002)_{\alpha-M g}$ diffraction, the bright points verify the $14 \mathrm{H}$ type for the LPSO (Xu et al., 2013). The emerging of LPSO phase may be due to solid reactions between $(\mathrm{Gd}, \mathrm{Zn}$ ) elements with proper content ratio and condition in forming the $14 \mathrm{H}$ phase. The low concentration of solute atoms could lead to regular dislocations in the Mg matrix. The compression of solidly solved atoms also results in the decrease of lattice spacing along the c-axis.

\section{Extrusion Temperature Impact on Microstructures}

This subsection presents and discusses the influences of extrusion temperature on microstructures of the extruded samples. Figure 5 shows the optical micrographs of as-cast and extruded alloys along the longitudinal sections. As-cast alloy exhibits equiaxed microstructure with a grain size of about $25 \mu \mathrm{m}$, as seen in Figure 5A. Figures 5B-F show the optical micrographs of the $\mathrm{Mg}-2.0 \mathrm{Zn}-0.5 \mathrm{Zr}-3.0 \mathrm{Gd}$ alloy at various extrusion temperatures. Compared with the microstructure of the as-cast alloy, the whole extruded matrix was nearly bimodal-grained along the extrusion 

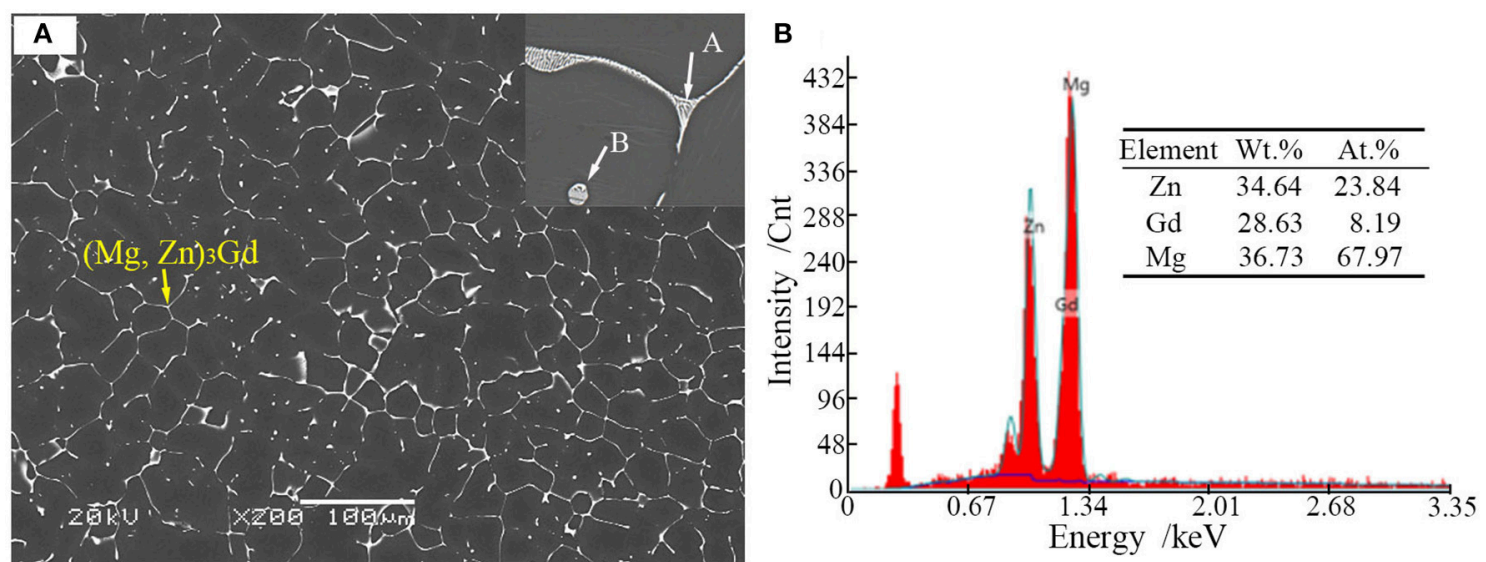

FIGURE 3 | (A) Scanning election microscopic image and enlarged image (onset) of the as-cast Mg-2.0Zn-0.5Zr-3.0Gd alloy; (B) EDS analysis results of the eutectic compounds.
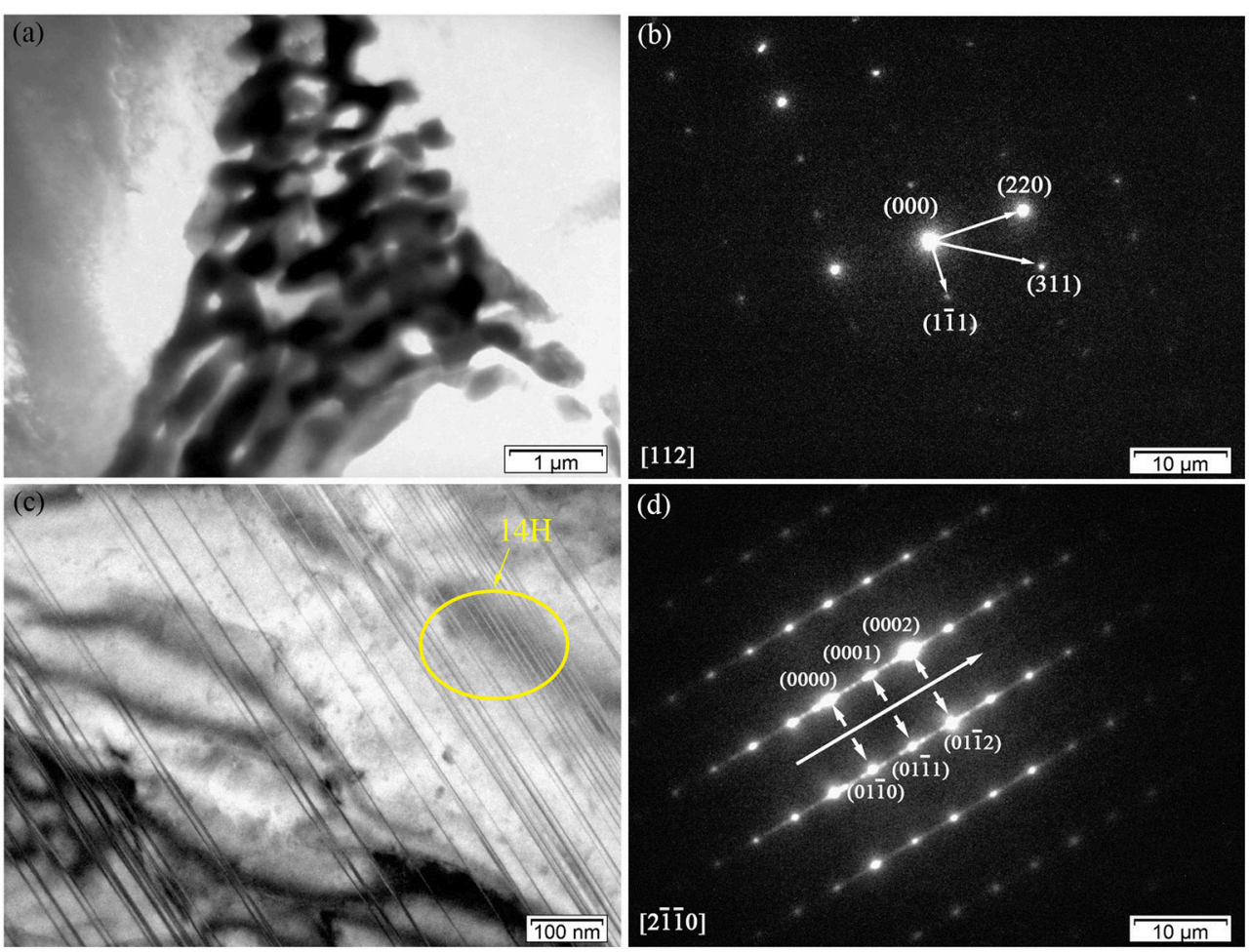

FIGURE 4 | Microstructure of the as-cast Mg-2.0Zn-0.5Zr-3.0Gd alloy: (a) BF TEM image of continuous network eutectic phase; (b) SAED pattern corresponding to the eutectic phase; (c) BF TEM image of the LPSO phase distributed inside the grains; (d) SAED pattern corresponding to the LPSO phase.

direction, which contains both the non-dynamic recrystallized (unDRXed) deformed grains and fine DRXed grains. Large deformed grains have strong basal texture and fine recrystallized grains own weaker texture. The bimodal-grained microstructure is commonly observed in extruded Mg alloys (Du et al., 2015). The recrystallization starts from the grain boundary of the former grains and the secondary phase, while the elongated grains are due to the extrusion (Homma et al., 2010). It could be seen that the area fraction of DRXed microstructure increased with extrusion temperature within the $330-350^{\circ} \mathrm{C}$ range, followed by a decrease at $350-370^{\circ} \mathrm{C}$. The area fraction of DRXed microstructure and grain size of E350 are estimated to be about $95 \%$ and $5 \mu \mathrm{m}$, respectively. The cast microstructure of the $\mathrm{Mg}$ 2.0Zn-0.5Zr-3.0Gd alloy after extrusion completely disappeared. The grain size of the alloy was obviously refined, and the microstructure in the interior of the alloys had no cracks nor 


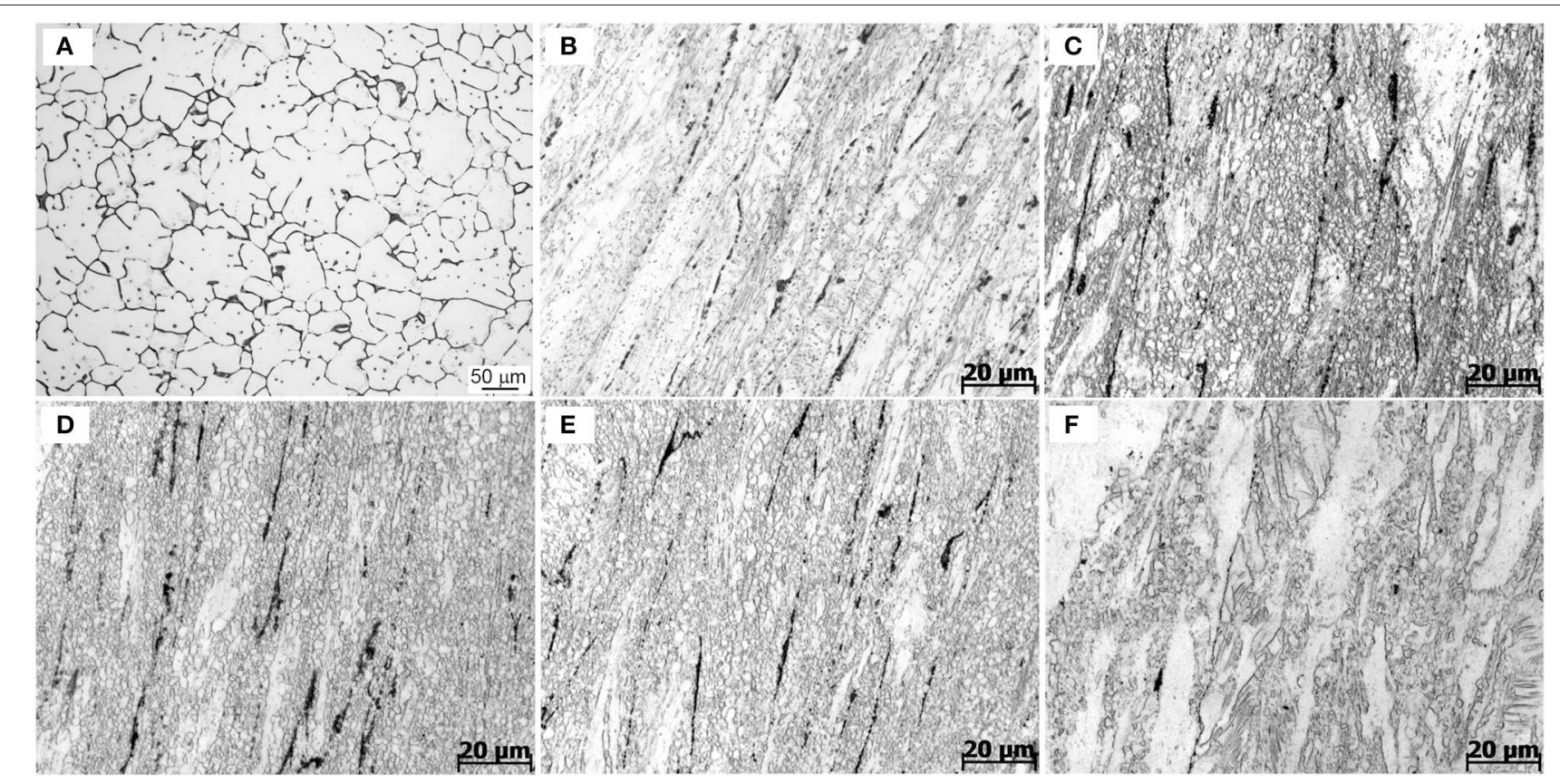

FIGURE 5 | Optical images of the Mg-2.0Zn-0.5Zr-3.0Gd alloys: (A) As-cast;(B) E330; (C) E340; (D) E350; (E) E360; and (F) E370.

pores. The continuous secondary phase was mainly changed into black parallel strips distributed along the extrusion direction. The secondary phase has been plastically deformed during extrusion, which acted as the preferred DRXed nucleation sites and stimulated nucleation of the DRXed grains in Figures 5C-E (Robson et al., 2009). Furthermore, stress concentration occurred near secondary phases, resulting in dislocations piling up. These accumulations promoted the nucleation of recrystallized grains and enhanced the DRX during the extrusion process. When infused with REs, the Mg alloys turn to have finer recrystallized grains during extrusion and rolling processes (Luo et al., 2014).

Remarkably in Figures 5C-E, many DRXed grains are not only evolved at the original grain boundaries, but also inside of grains. The experimental evidences indicate that with increasing extrusion temperature, more slip systems are activated and the effects of plastic anisotropy are weaker. This results in the occurrence of a more homogeneous deformation and simultaneously the increase of the DRX ratio (Zhang et al., 2015). The DRX partly occurred in the extrusion process, while the grains were simultaneously refined. The large shear force caused the alloy to break and distribute in the matrix.

The temperature has a prominent role to determine the extrusion microstructures. The actual extrusion temperature is not the same as the initial sample temperature due to the heat generation from deformation heat, friction heat, and heat dissipation to the surroundings. Increasing temperature could further refine the grains to be more uniform in the $330-350^{\circ} \mathrm{C}$ range. When the temperature was set to $330^{\circ} \mathrm{C}$, the DRX was not evolved. The rather coarse grains are not uniform in size. When the extrusion temperature was increased to $350^{\circ} \mathrm{C}$, the grain size decreased significantly and became more uniform. More grain nucleation happened at higher temperature. This is due to a large quantity of plastic deformation when the extrusion ratio is nearly 8 , which provides favorable conditions for the recrystallization. The nucleation of DRX also requires a critical temperature of deformation, and can occur when the actual deformation temperature reaches a critical temperature. The secondary phase, with a relatively high melting point, can pin grain boundaries and hindered grain growth during hot extrusion. In this case, the change of grain shapes is not obvious, as the extrusion temperature increases from 340 to $360^{\circ} \mathrm{C}$. However, when the extrusion temperature reaches $370^{\circ} \mathrm{C}$, the thermal stability of the secondary phase decreases, and the pinning effect of particles is rapidly weakened. Therefore, a significant grain coarsening occurs at $370^{\circ} \mathrm{C}$. Thus, recrystallization depends on both temperature and extrusion ratio, and the temperature determines the nucleation rate. The amount of grain growth is controlled by temperature at certain extrusion ratios.

Figure 6a shows the BF image of the particles with a submicrometer size distributed at the grain boundaries in the E330 sample. It can also be speculated that large sized secondary phase grains existed in the as-cast alloy and were broken into smaller ones. Two kinds of lattice structures were observed in the SAED patterns in Figure 6b. One was hexagonal close packed (hcp) lattice of $\alpha-\mathrm{Mg}$, and another the particle fcc phase. In the particle phase of the hot extruded alloy, the SAED pattern was similar to that of the as-cast alloy with fcc signature. With a calculated lattice parameter of $\sim 0.721 \mathrm{~nm}$, the hot extruded alloy was identified as $(\mathrm{Mg}, \mathrm{Zn})_{3} \mathrm{Gd}$, similar to those observed in the as-cast alloy (see Figure 4). However, this number is smaller than $0.729 \mathrm{~nm}$ of the as-cast, indicating more dissolution of $\mathrm{Zn}$ into the $(\mathrm{Mg}, \mathrm{Zn})_{3} \mathrm{Gd}$ phase from the $\alpha-\mathrm{Mg}$ matrix after hot extrusion. As 

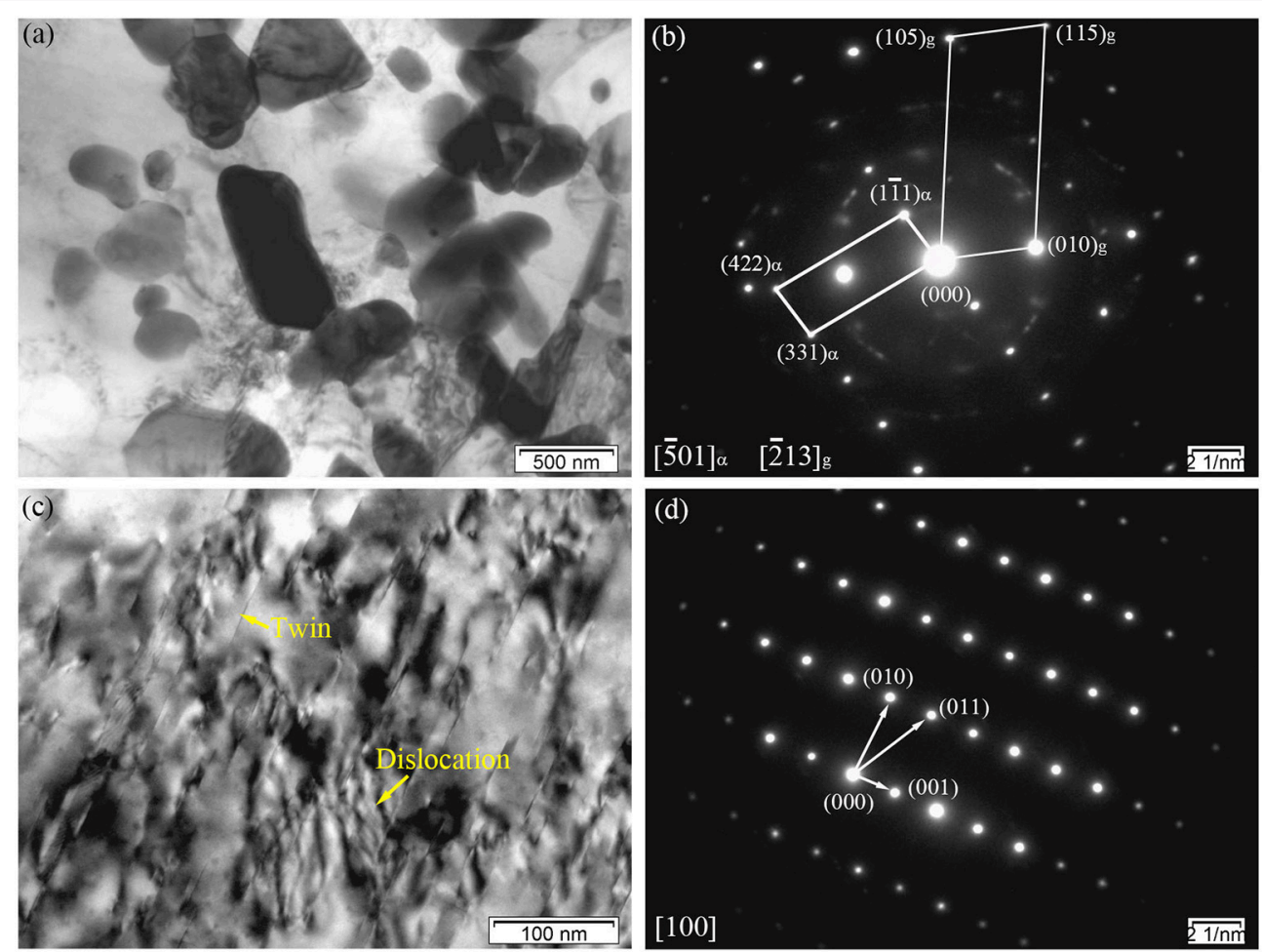

FIGURE 6 | Microstructure of the E330 sample: (a,c) BF images; (b) Corresponding SAED pattern of (a); (d) Corresponding SAED pattern of (c)

shown in Figure 6c, twins and dislocations are observed within the grains. The LPSO phases also turn up here, similar to the observation in Figure 4c. However, instead of LPSO phase, a large number of twin crystals was found inside the grains. The corresponding SAED patterns shown in Figure $6 \mathbf{d}$ further prove the twins are $\alpha-\mathrm{Mg}$. We attribute the origin as follows. Typically the dislocations are generated during hot extrusion. In addition, dislocations pile-up at twin boundaries, which could induce subgrain formation and contribute to recrystallization (Sun et al., 2016). Deformation twinning is an important mechanism in compressive stress along the c-axis, while twin crystals facilitate deformation and increase plasticity.

With increased extrusion temperature, the activation of non-basal slip systems is more likely to occur since the value of critical resolved shear stress decreases rapidly with temperature. This can be seen in Figures $7 \mathbf{a}, \mathbf{b}$, where the twinning deformation of the E350 sample decreased compared to E330. In addition, the activation of twinning is suppressed with extrusion temperature, and a transition from twin-dominated to slip-dominated deformation may occur (Huang and Log, 2016). A small quantity of deformation twins exist in the $\alpha-\mathrm{Mg}$ matrix far from the secondary phase.

Figure 8 displays the TEM micrographs of the E350 sample. In Figure 8a, the BF image shows loosely dispersed rod-like precipitates with $100-400 \mathrm{~nm}$ length and $20 \mathrm{~nm}$ width. The darkfield image in Figure $\mathbf{8 b}$ shows rod-like precipitates oriented along the ED. According to the SAED pattern in Figure 8c, the rod-like precipitated phase was also found to have an fcc structure with $\mathrm{a}=0.722 \mathrm{~nm}$. Hence, this rod-like precipitated phase was confirmed to have $(\mathrm{Mg}, \mathrm{Zn})_{3} \mathrm{Gd}$ phase, similar to the $\mathrm{Mg}_{3} \mathrm{Gd}$ type with $\mathrm{Zn}$ dissolved in the structure.

In addition, some of nanoscale elliptical particles stay within $\alpha-\mathrm{Mg}$ matrix, as seen in Figures 8d,e. The average size of the elliptical particles is within $5-20 \mathrm{~nm}$ range. According to the SAED pattern in Figure 8f, the elliptical particles have a primitive cubic lattice structure with $\mathrm{a}=0.865 \mathrm{~nm}$. Therefore, these elliptical particles are suggested to have the $\mathrm{Mg}_{2} \mathrm{Zn}_{11}$ phase with their axis parallel to the $[3 \overline{6} 4]$ direction. Noticing the absence in as-cast alloys, the $\mathrm{Mg}_{2} \mathrm{Zn}_{11}$ phase is formed only after extrusion in the $\mathrm{Mg}-2.0 \mathrm{Zn}-0.5 \mathrm{Zr}-3.0 \mathrm{Gd}$ alloy. This may be due to the redistribution of $\mathrm{Zn}$ element in the matrix at high temperatures, which precipitated as the $\mathrm{Mg}_{2} \mathrm{Zn}_{11}$ phase during the extrusion process.

As illustrated in Figures 8a-f, these nanoscale rod-like and elliptical particles tend to precipitate in the DRXed areas rather than the original precipitated phase breakage. This means that a high deformation temperature can cause the partial dissolution of pre-existing $(\mathrm{Mg}, \mathrm{Zn})_{3} \mathrm{Gd}$ precipitates. Some nanoscale rod-like and elliptical particles dispersed in the matrix at a temperature range of $340-360^{\circ} \mathrm{C}$. Thus, dynamic precipitation can also occur during extrusion at appropriate deformation temperatures, and yield many nanoscale precipitated phases in the extruded alloy.

Figure 9 shows typical TEM micrograph of the E350 samples. In Figure 9A, an intensive dispersion of rod-like precipitates 

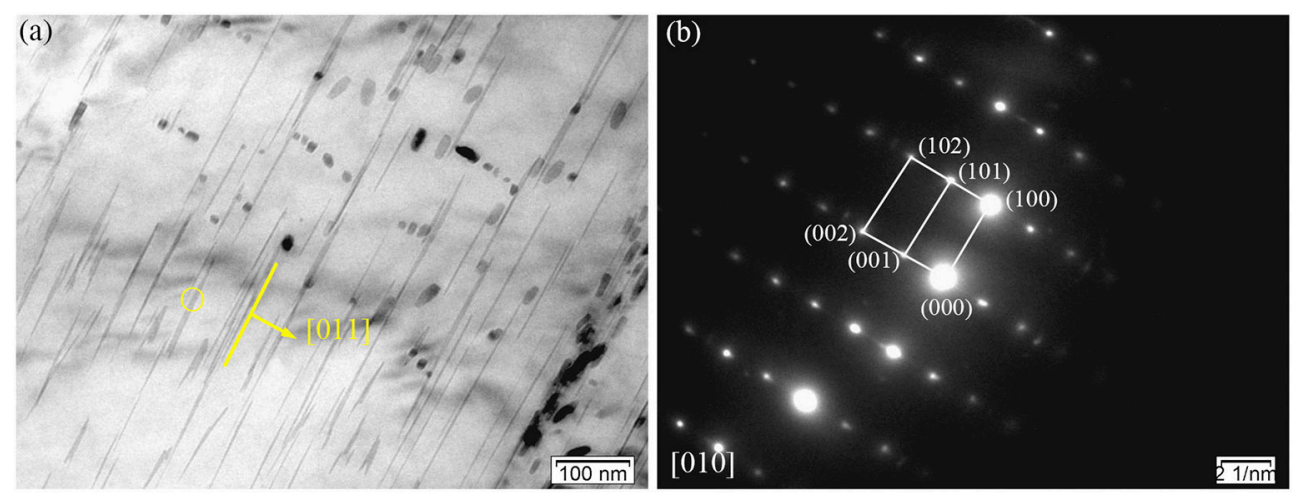

FIGURE 7 | Microstructure of the E350 sample: (a) BF image; (b) Corresponding SAED pattern.

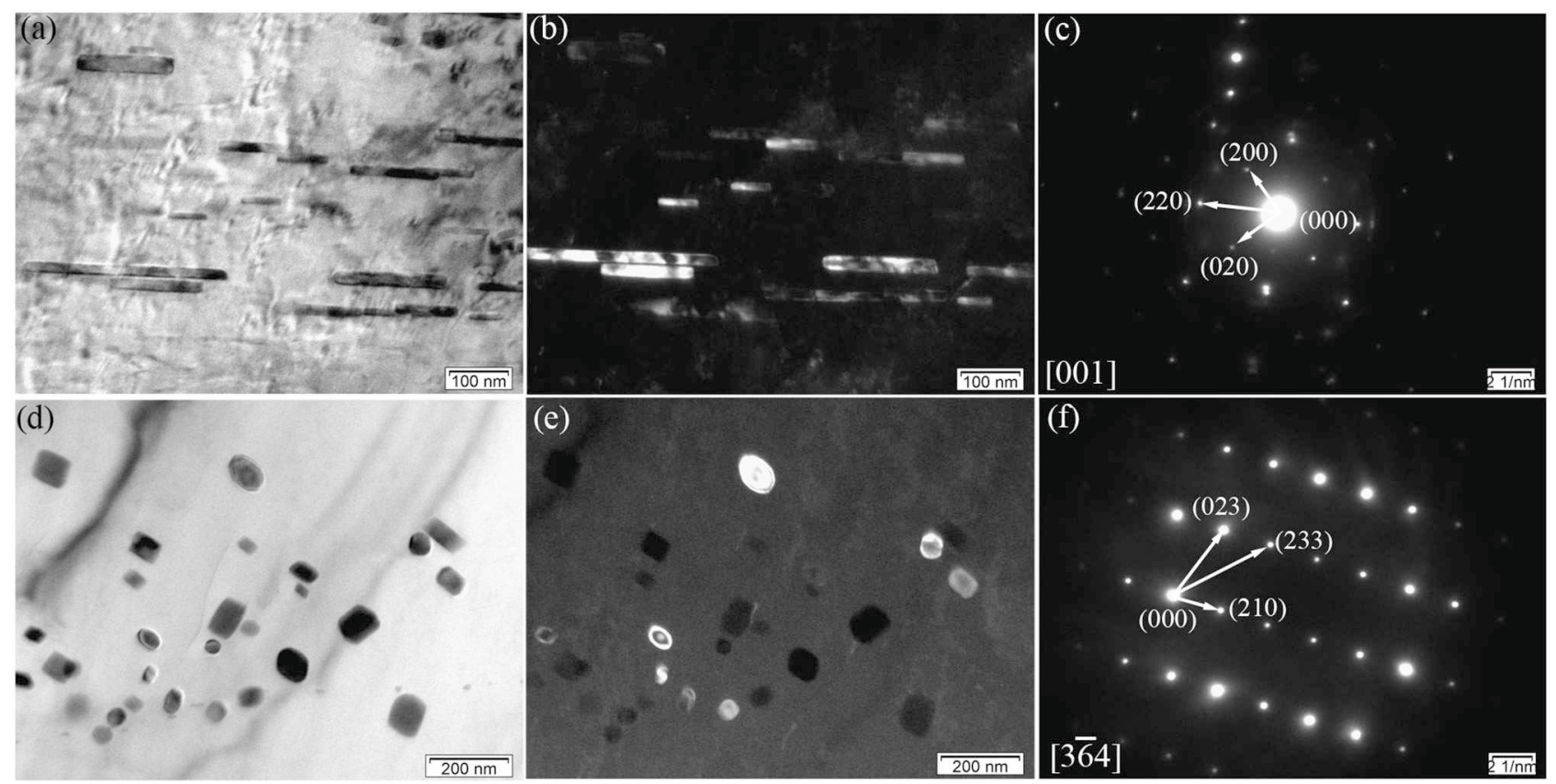

FIGURE 8 | Microstructure of the E350 sample; (a,b) BF and dark-field micrographs of the rod-like precipitates; (c) Corresponding SAED pattern of (a,b); (d,e) BF and dark-field micrographs of the grain-like precipitates; (f) Corresponding SAED pattern of (d,e).

are found parallel to ED. They own the (Mg, $\mathrm{Zn})_{3} \mathrm{Gd}$ phase, according to previous determination. The rod-like form of the $(\mathrm{Mg}, \mathrm{Zn})_{3} \mathrm{Gd}$ phase can be seen as the dissolution and reprecipitation of the pre-existing $(\mathrm{Mg}, \mathrm{Zn})_{3} \mathrm{Gd}$ phase during hot extrusion. A random distribution of granular precipitates in the $\alpha-\mathrm{Mg}$ matrix is obvious in Figure 9B. The granular form of $\mathrm{Mg}_{2} \mathrm{Zn}_{11}$ (Figure 8F) becomes a newly precipitated phase in the extrusion process. A large number of $\mathrm{Mg}_{2} \mathrm{Zn}_{11}$ phase particles exist in the DRXed region. They have the grain size of $10-30 \mathrm{~nm}$.

From Figures 9C,D, these precipitates distribute heterogeneously within DRXed grains and some boundaries of DRXed grains. In addition, some dislocations can be observed within the grains. It should be noted that the size of the DRXed grains is about $2-6 \mu \mathrm{m}$. These precipitates can form during extrusion and influence the recrystallization behavior. As for the recrystallization behavior, the precipitates can act as nucleation sites during the process, and may also exert a significant pinning effect on the grain boundaries. Indeed, precipitates can either promote or suppress recrystallization, depending on their morphologies such as size, shape, volume fraction, and spacing (Sun et al., 2016). As seen in Figures 9C,D, the $\mathrm{Mg}_{2} \mathrm{Zn}_{11}$ phase particles, with the $20-50 \mathrm{~nm}$ size, and rod-like form of $(\mathrm{Mg}, \mathrm{Zn})_{3} \mathrm{Gd}$ phase, with the $50-200 \mathrm{~nm}$ size in length and $20 \mathrm{~nm}$ in width, mainly occur in the DRXed region. Fine secondary phase particles tend to hinder boundary motion by slowing down recrystallization and grain growth. In contrast, coarse secondary phase particles can accelerate recrystallization by particle-stimulated nucleation due to the 

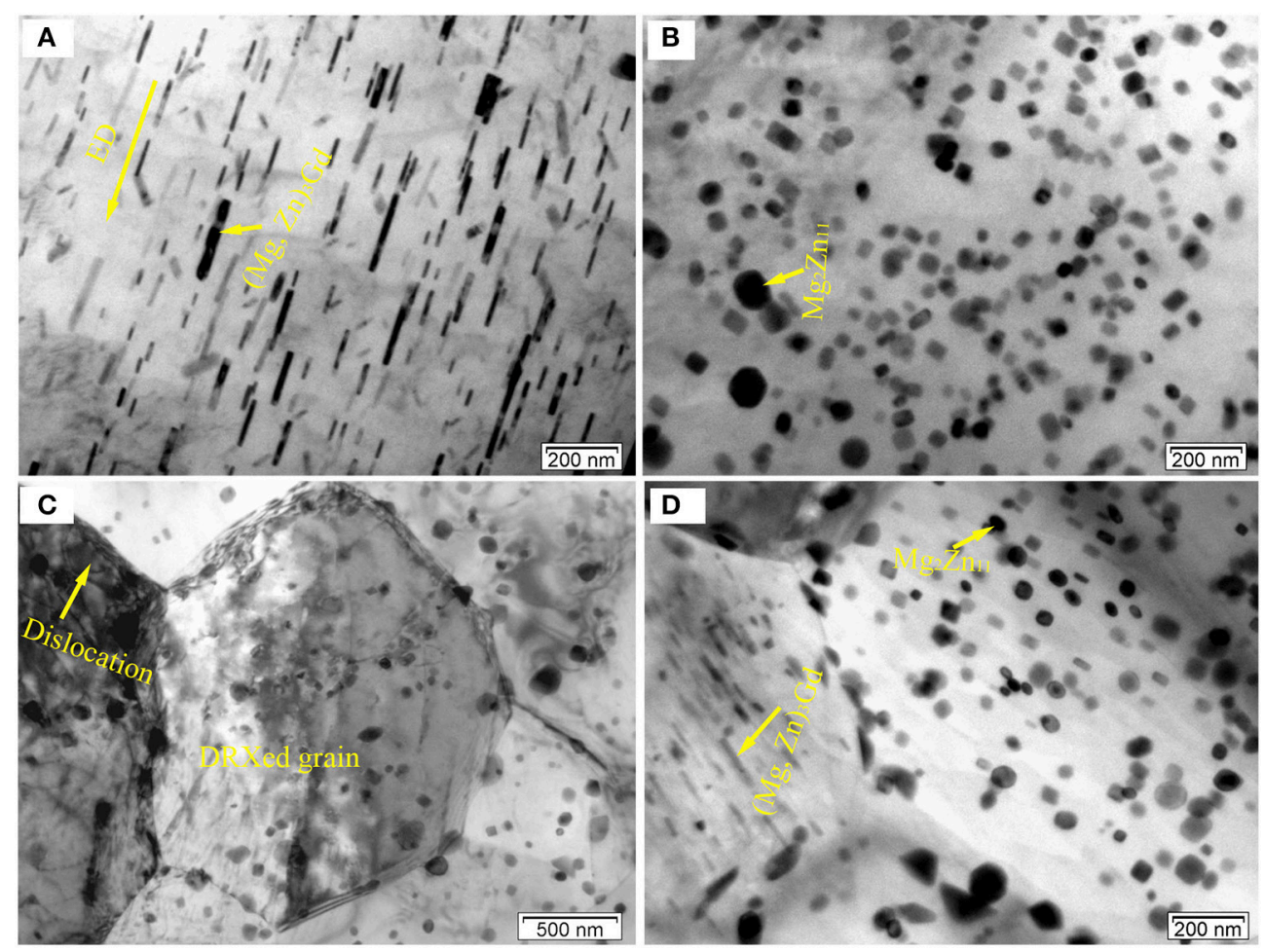

FIGURE 9 | Typical TEM BF images of the E350 samples: (A) A large amount of rod-like precipitates; (B) A large amount of granular precipitates; (C,D) Rod-like and granular precipitates at the grain boundaries or within crystals.

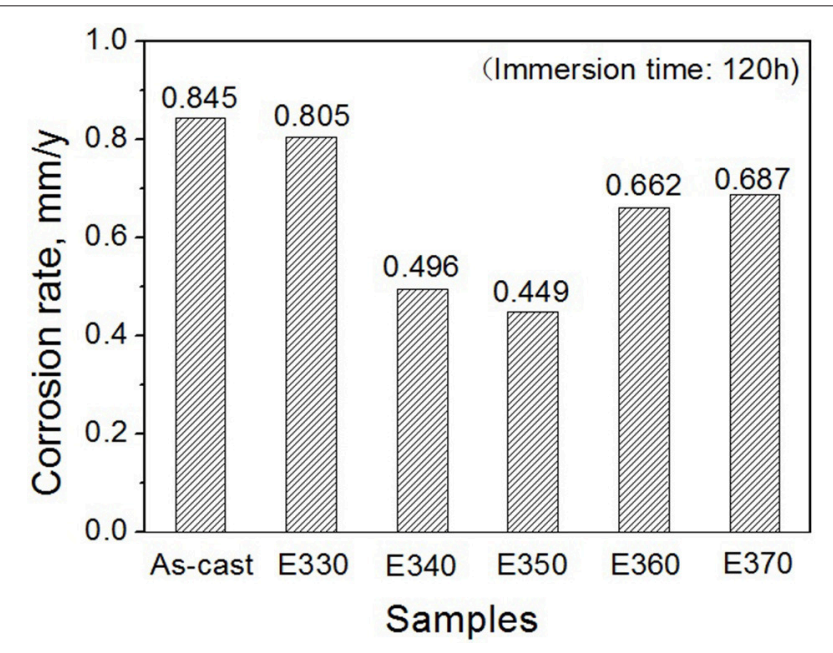

FIGURE 10 | Corrosion rates for Mg-2.0Zn-0.5Zr-3.0Gd alloy measured by weight loss after immersed for $120 \mathrm{~h}$.

large amount of stored energy in the deformation zones (Hou et al., 2011). This means that these (Mg, $\mathrm{Zn})_{3} \mathrm{Gd}$ and $\mathrm{Mg}_{2} \mathrm{Zn}_{11}$ phase particles, with sizes far less than $1 \mu \mathrm{m}$, inhibit grain boundary migration. Therefore, these fine secondary phase particles may contribute to grain refinement via grain boundary pinning.

\section{Anti-corrosive Tests}

The anticorrosion results in the immersion test is evaluated through weight loss rate $\Delta W\left(\mathrm{mg} / \mathrm{cm}^{2} / \mathrm{d}\right)$. This can be translated to an average corrosion rate $(\mathrm{mm} / \mathrm{y})$ using

$$
P_{w}=3.65 \Delta W / \rho
$$

Where $\rho$ is the alloys density $\left(\mathrm{g} / \mathrm{cm}^{3}\right)$ (Shi et al., 2010). Figure 10 depicts the loss rates for the studied samples after $120 \mathrm{~h}$ immersions. Obviously, the extruded alloys own better resistances to the SBF compared to the as-cast one. With the increase of the extrusion temperature, the rate first dropped, reached the minimum at E350, and increased afterwards. The corrosion products and alloy surface morphology after immersion were studied through the SEM and EDS. As shown in Figures 11A-F, all immersed alloys have similar microstructures composed of white loose corrosion (e.g., Point A in Figure 11B) and tightly bounded products (e.g., Point B in Figure 11B). Irregular cracks are due to the loss of moisture in air during the drying process. The element analysis of the sample E330 shows that the corrosion products at $\mathrm{A}$ and $\mathrm{B}$ are composed of $\mathrm{O}, \mathrm{Mg}, \mathrm{P}$, and $\mathrm{Ca}$ elements. The proportion of the quality of the elements is relatively similar, as given in Table 2 . The crystal structures of corrosion products were determined through XRD. Result in Figure 12 proves the existence of the main composites of $\mathrm{Mg}, \mathrm{Mg}(\mathrm{OH})_{2}, \mathrm{Ca}_{10}\left(\mathrm{PO}_{4}\right)_{6}(\mathrm{OH})_{2}$, and $(\mathrm{Ca}, \mathrm{Mg})_{3}(\mathrm{PO} 4)_{2}$. During the immersion, $\mathrm{OH}^{-}, \mathrm{Ca}^{2+}, \mathrm{H}_{2} \mathrm{PO}_{4}^{-}$, and $\mathrm{HPO}_{4}^{2-}$ in the SBF reacted with magnesium. The product hydroxyapatite 

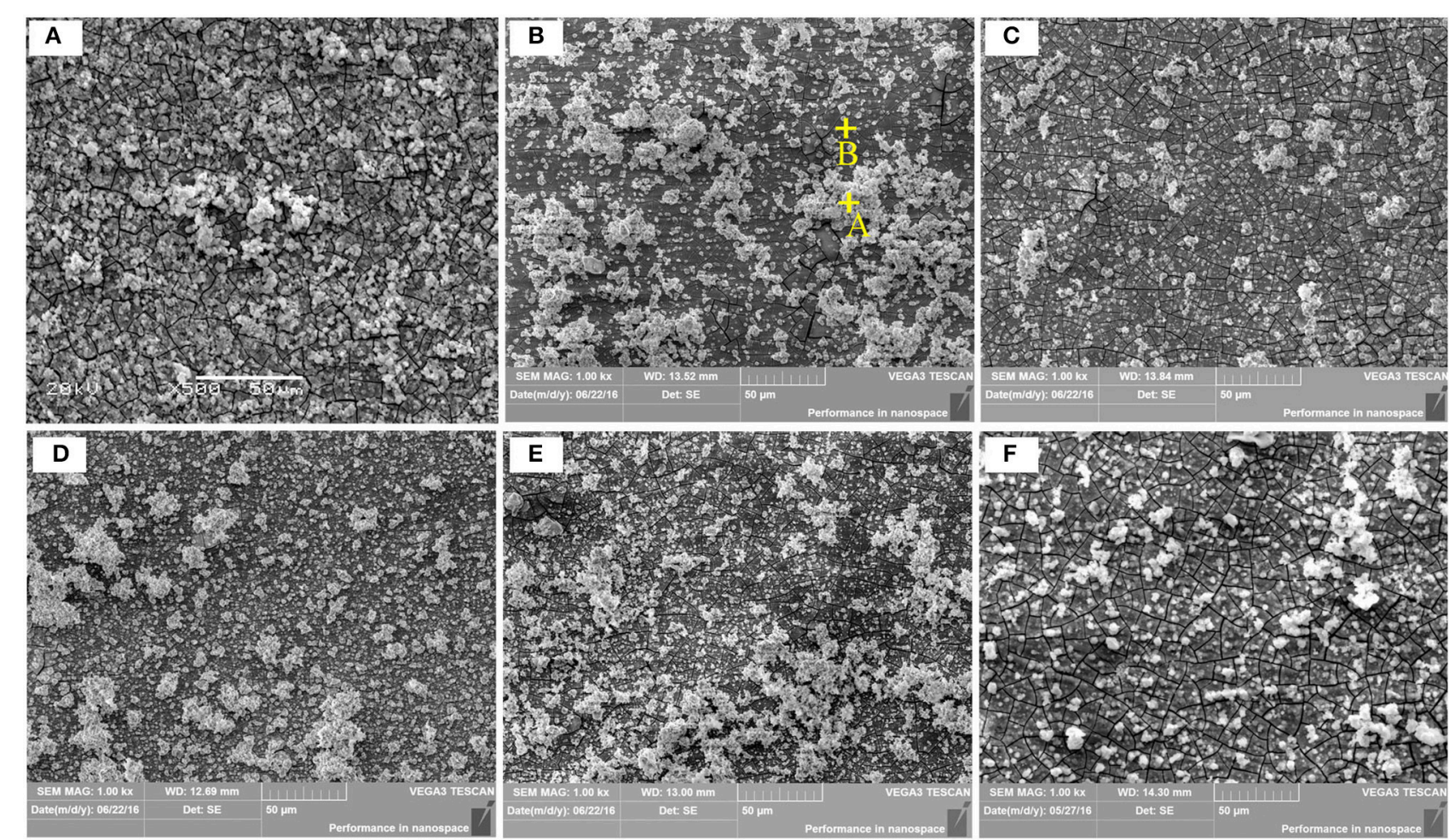

FIGURE 11 | Corrosion micrographs of the as-cast Mg-2.0Zn-0.5Zr-3.0Gd alloys after immersion in SBF for $120 \mathrm{~h}$. (A) As-cast; (B) E330; (C) E340; (D) E350; (E) E360; (F) E370.

TABLE 2 | EDS results of the E330 alloys after immersion in SBF for $120 \mathrm{~h}$ (wt.\%).

\begin{tabular}{lllll}
\hline Position & $\mathbf{O}$ & $\mathbf{M g}$ & $\mathbf{P}$ & $\mathbf{C a}$ \\
\hline A & 37.68 & 23.05 & 15.44 & 23.83 \\
B & 40.7 & 19.43 & 15.42 & 24.5 \\
\hline
\end{tabular}

$\left(\mathrm{Ca}_{10}\left(\mathrm{PO}_{4}\right)_{6}(\mathrm{OH})_{2}\right)$ particles can accelerate the bone healings in the human body (Zhang et al., 2012c). The as-cast and extruded alloys possess good biocompatibility.

Despite similar biocompatibility, anticorrosive abilities differ from the as-cast and extruded samples. Figure 13 shows the surface morphology of the alloys after removing the etchant. For the as-cast alloy, it can be clearly seen from Figure 13a that the second phase at the microcrystal boundary acts as the cathode and the $\alpha-\mathrm{Mg}$ matrix as the anode inside the grains. Different electrochemical potentials between the matrix and the second phase in the SBF will lead the solvation via electrochemical corrosion for the matrix but not for the second phase. The network shape of the phase, on the other hand, set up boundaries to prevent the extension of the corrosions. A careful check inside of the corroded matrix further shows the existences of the tiny holes, mainly due to the electrochemical corrosions next to small amount of the second phase dispersed inside of the matrix.

For the extruded alloy samples, the corrosion is uniform corrosion as shown in Figures 13b-f. This is attributed to the

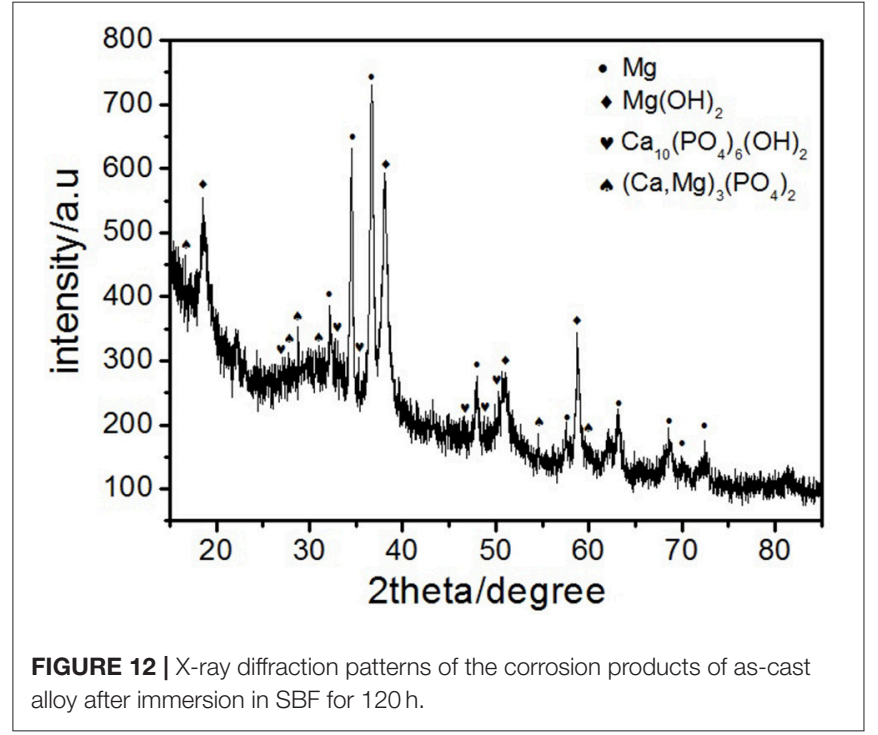

diminishing of differences between electrochemical potentials of the matrix and precipitations. During the extrusion, a large number of nanoscale rod-like $(\mathrm{Mg}, \mathrm{Zn})_{3} \mathrm{Gd}$ and granular $\mathrm{Mg}_{2} \mathrm{Zn}_{11}$ were precipitated, and uniformly distributed in the magnesium matrix as shown in Figure 8. A certain amount of alloying elements merged into the matrix, increasing the 


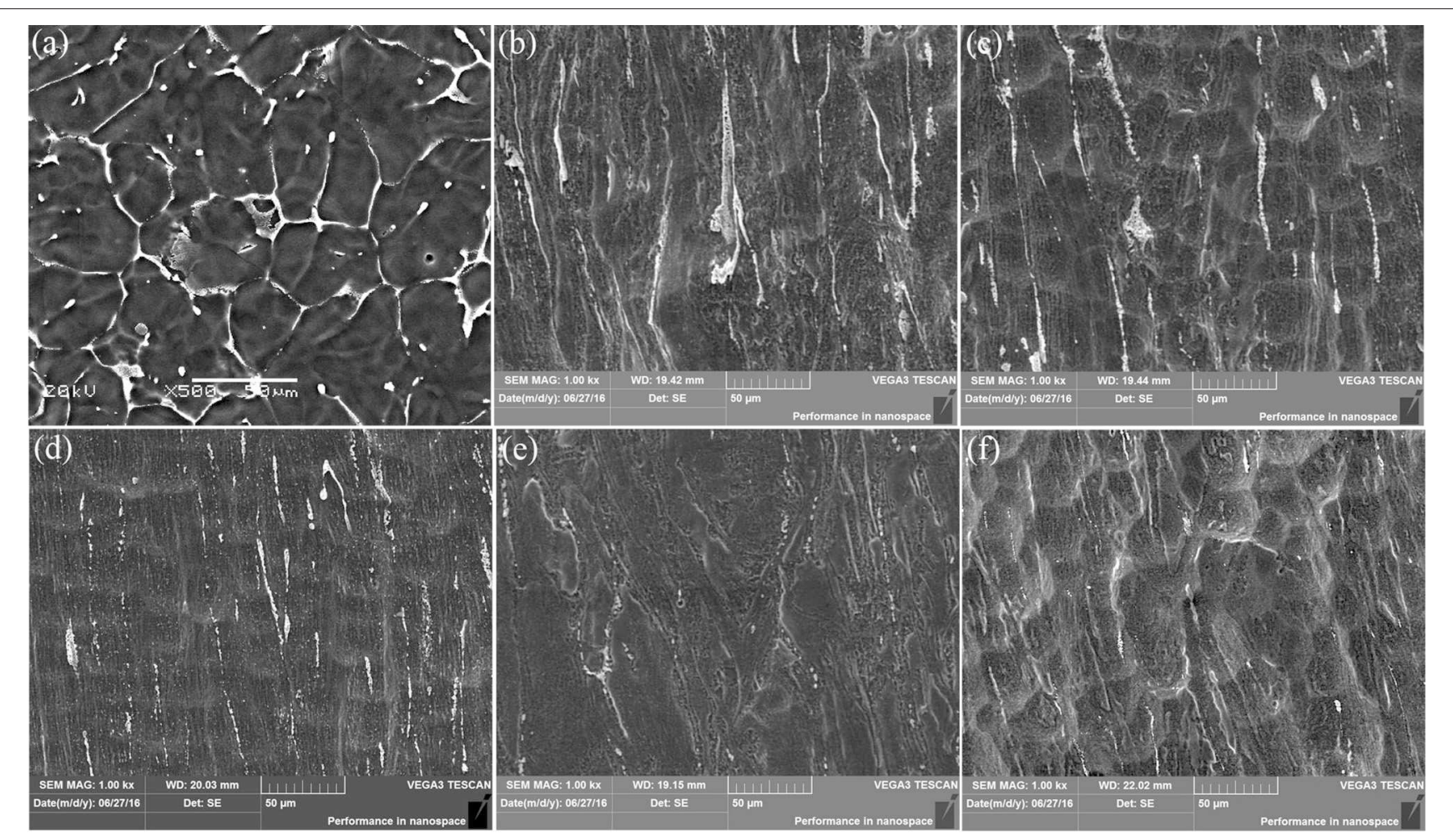

FIGURE 13 | SEM micrographs showing the corroded Mg-2.0Zn-0.5Zr-3.0Gd samples after immersion for $120 \mathrm{~h}$ and corrosion product removal: (a) As-cast; (b) E330; (c) E340; (d) E350; (e) E360; (f) E370.

electrochemical potential of the $\alpha-\mathrm{Mg}$, and reducing the difference correspondingly. The potential difference becomes smaller between the second phase and the matrix of the $\alpha-\mathrm{Mg}$. During the immersion, the $\alpha-\mathrm{Mg}$ anode was slowly dissolved, resulting in uniform corrosion. This discovery is in line with the previous research where the $\mathrm{Mg}_{2} \mathrm{Zn}_{11}$ phase can enhance the anticorrosive properties of the Mg alloys (Byun et al., 2013).

The surface morphology of the corroded alloys also follows the trend given by the extrusion temperature. Again, this is due to the temperature impacts on the microstructural changes. E350 has the best uniformity. This is not surprising because it owns the most abundant and best distributed DRXed grains, and a small amount of deformation of these grains. Taking the surface properties of another 4 immersed samples into consideration, it is generally found that the corrosion uniformity follows the ratio of the DRXed grains to the large deformed grains. A bigger ratio leads to a better uniformity.

To crosscheck the immersion result, we analyzed the potentiodynamic polarization curves of the Mg-2.0Zn-0.5Zr3.0Gd alloys performed on the electrochemical workstation. The curves were depicted in Figure $\mathbf{1 4}$ for the extruded samples and the as-cast one, and corresponding potential $\mathrm{E}_{\mathrm{corr}}$ and current $\mathrm{I}_{\text {corr }}$ were listed in Table 3. Following the Tafel algorithm (Choi et al., 2012), the corrosion rates $\left(\mathrm{P}_{\mathrm{i}}\right)$ were also calculated and listed in the table. From the figure and table, it is obvious that the self-corrosion potentials are all above the original value of the as-cast, denoting smaller corrosive speed after extrusion.

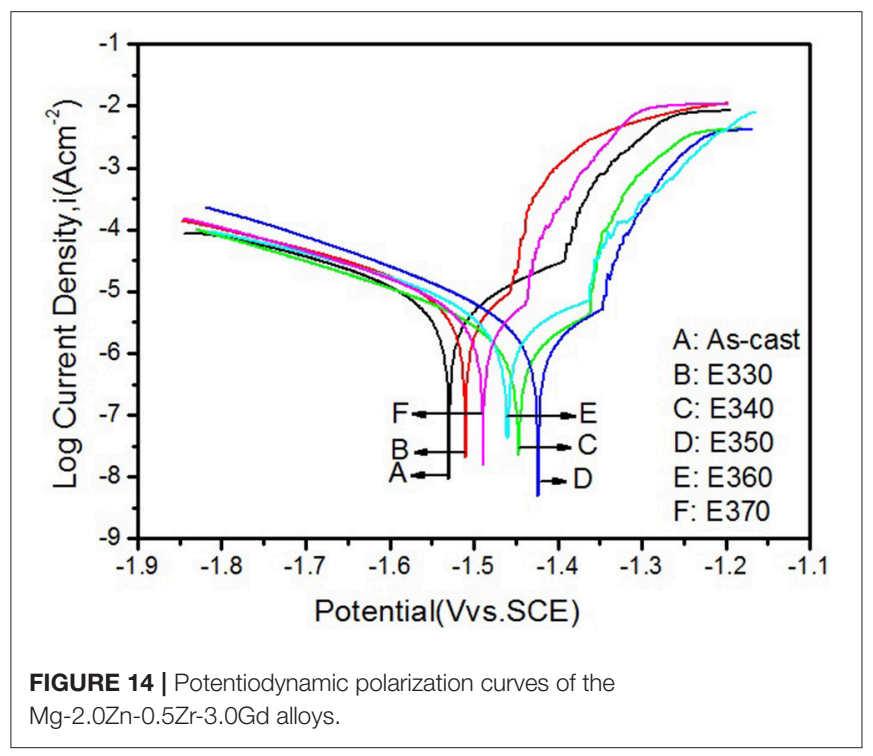

The extrusion temperature yields increase of the potentials for E330-E350, and then retreat of the values from E350-E370. Correspondingly, the anticorrosive properties were enhanced, and then weakened. The best performance is found for the E350 sample with the parameters of $\mathrm{E}_{\text {corr }}=-1.423 \pm 0.003 \mathrm{~V}, \mathrm{I}_{\text {corr }}=$ $3.226 \pm 0.005 \mathrm{uAcm}^{-2}$ and the $\mathrm{P}_{\mathrm{i}}$ of $0.146 \pm 0.003 \mathrm{~mm} / \mathrm{y}$. 
TABLE 3 | Values measured from potentiodynamic and $P_{\mathrm{i}}$ of Mg-2.0Zn-0.5Zr-3.0Gd alloys.

\begin{tabular}{|c|c|c|c|c|c|c|}
\hline Material & As-cast & E330 & E340 & E350 & E360 & E370 \\
\hline $\mathrm{E}_{\text {Corr }}(\mathrm{Vvs.SCE})$ & $-1.530 \pm 0.004$ & $-1.507 \pm 0.003$ & $-1.448 \pm 0.003$ & $-1.423 \pm 0.003$ & $-1.478 \pm 0.002$ & $-1.49 \pm 0.004$ \\
\hline $\mathrm{I}_{\mathrm{Corr}}\left(\mathrm{uAcm}^{-2}\right)$ & $7.686 \pm 0.006$ & $5.662 \pm 0.004$ & $3.507 \pm 0.004$ & $3.226 \pm 0.005$ & $4.031 \pm 0.003$ & $4.629 \pm 0.005$ \\
\hline $\mathrm{P}_{\mathrm{i}}(\mathrm{mm} / \mathrm{y})$ & $0.343 \pm 0.002$ & $0.255 \pm 0.003$ & $0.158 \pm 0.003$ & $0.146 \pm 0.003$ & $0.182 \pm 0.002$ & $0.209 \pm 0.003$ \\
\hline
\end{tabular}

Physical origins for the potentiodynamic results are similar to the one given by immersion results, where relative larger amount of the DRXed grains offer smaller electrochemical potential differences once they were evenly merged into the matrix, and increase the potentials. The refined grains can enhance the alloy passivity by introducing smaller potential gradient into the system (Argade et al., 2012).

Despite the consistency of corrosion tests, higher static corrosion rates were noticed in the immersion test than these given by the Tafel algorithm. This is mainly arisen from the corrosive processes of the biometals. In the SBF, corrosion debuts from a passivation stage where the rate is rather low. At the middle stage, the rate increases due to the occurrence of electrochemical corrosion. After longer soaking time, the corroded layer gradually becomes thicker and prevent further chemical reactions. The rate becomes smaller, and the alloy tends to stable in the SBF (Abidin et al., 2011). The polarization curves mainly serve the rates at the first stage, and lead to smaller values compared to these given by static immersion tests.

We also evaluated the biosafety of the present implanting materials inside of human body. When the extrusion temperature is $350^{\circ} \mathrm{C}$, the average dissolution of $\mathrm{Gd}$ in the first $120 \mathrm{~h}$ is about $0.0067 \mathrm{mg} / \mathrm{cm}^{2} / \mathrm{d}$ in the SBF. Assuming the exposing area is about $50 \sim 100 \mathrm{~cm}^{2}$ of the implant, a total daily release of the $\mathrm{Gd}$ is calculated to $0.335 \sim 0.67 \mathrm{mg}$. This number is much lower than $4.2 \mathrm{mg}$ of daily absorption rate of rare earth elements in human body (Chen et al., 2014), indicating the total absorption of the released $\mathrm{Gd}^{3+}$. Typically, $10 \mathrm{~g}$ of the alloys is needed for the bone fracture fixation materials (Heublein et al., 2003; Seitz et al., 2016). Suppose a total degradation of the alloy implanted in a $70 \mathrm{~kg}$ human body happened, the LD50 level is calculated to 0.027 $\mathrm{mmol} / \mathrm{kg}$, much less than the Gd LD50 safe criterion of $0.1 \sim 0.3$ $\mathrm{mmol} / \mathrm{kg}$ in human (Bousquet et al., 1988). Thus, the alloy is safe.

\section{CONCLUSION}

In conclusion, we have successfully tailored the microstructural and anticorrosive properties of the $\mathrm{Mg}-2.0 \mathrm{Zn}-0.5 \mathrm{Zr}-3.0 \mathrm{Gd}$

\section{REFERENCES}

Abidin, N. I. Z., Atrens, A. D., Martin, D., and Atrens, A. (2011). Corrosion of high purity Mg, Mg2Zn0.2Mn, ZE41 and AZ91 in Hank's solution at 37? Corros. Sci. 53, 3542-3556. doi: 10.1016/j.corsci.2011.06.030

Argade, G. R., Panigrahi, S. K., and Mishra, R. S. (2012). Effects of grain size on the corrosion resistance of wrought magnesium alloys containing neodymium. Corros. Sci. 58, 145-151. doi: 10.1016/j.corsci.2012.01.021 (wt.\%) alloy by tuning the extrusion temperature. The network of the fish-bone shaped, ellipsoidal $(\mathrm{Mg}, \mathrm{Zn})_{3} \mathrm{Gd}$ phases, and lamellar LPSO phases in the as-cast Mg-2.0Zn-0.5Zr-3.0Gd (wt.\%) alloy are modified to unDRXed deformed grains and fine DRXed grains. The area fraction of DRXed microstructure increased with extrusion temperature at the $330-350^{\circ} \mathrm{C}$ range but decreased at the $350-370^{\circ} \mathrm{C}$ range. The large sized secondary phases in the as-cast alloy were broken into particles with submicron size distributed at the grain boundaries in the E330 sample, while the secondary phase of the E350 sample was composed of rod-like $(\mathrm{Mg}, \mathrm{Zn})_{3} \mathrm{Gd}$ grains parallel to the extrusion direction and granular $\mathrm{Mg}_{2} \mathrm{Zn}_{11}$ phase. Along with their good biocompatibility, the as-extruded alloys own better anticorrosive performances in the SBF compared to the as-cast counterpart, with the one extruded at $350^{\circ} \mathrm{C}$ topping. Enhancement of the resistivity is attributed to the DRXed grains and their distributions in the matrix after extrusion in proper temperature, where electrochemical potentials of the biometallic systems can be modified accordingly.

\section{AUTHOR CONTRIBUTIONS}

HY participated in the design of the manuscript and drafted the manuscript. J-BW analyzed experimental results. YX and YL carried out experiments. MH revised the manuscript.

\section{ACKNOWLEDGMENTS}

This work was supported by the Henan New Nonferrous Metal Materials University Science and Technology Innovation Team Support Program of China (2012IRTSTHN008), the Program for Science, Technology Innovation Talents in Universities of the Henan Province (17HASTIT026), the Science and Technology Project of the Henan Province (152102210077), Education Department of the Henan Province (16A430005), and the Science and Technology Innovation Team of the Henan University of Science and Technology (2015XTD006). Daroonparvar, M., et al. (2014). Mechanical and bio-corrosion properties of quaternary $\mathrm{Mg}-\mathrm{Ca}-\mathrm{Mn}-\mathrm{Zn}$ alloys compared with binary $\mathrm{Mg}$-Ca alloys. Mater. Des. 53, 283-292. doi: 10.1016/j.matdes.2013.06.055

Bousquet, J. C., Saini, S., Stark, D. D., Hahn, P. F., Nigam, M., Wittenberg, J., et al. (1988). Gd-DOTA: characterization of a new paramagneitc complex. Radiology 166, 693-698. doi: 10.1148/radiology.166.3.33 40763 
Byun, J. M., Yu, J. M., Kim, D. K., Kim, T. K., Jung, W. S., and Kim, Y. D. (2013). Corrosion behavior of Mg2Zn11 and MgZn2 single phase. J. Korean Inst. Met. Mater. 51, 413-419. doi: 10.3365/KJMM.2013.51.6.413

Chen, Y. J., Xu, Z. G., Smith, C., and Sankar, J. (2014). Recent advances on the development of magnesium alloys for biodegradable implants. Acta Biomater. 10, 4561-4573. doi: 10.1016/j.actbio.2014.07.005

Choi, Y. I., Salman, S., Kuroda, K., and Okido, M. (2012). Improvement in corrosion characteristics of $\mathrm{AZ} 31 \mathrm{Mg}$ alloy by square pulse anodizing between transpassive and active regions. Corros. Sci. 63, 5-11. doi: 10.1016/j.corsci.2012.02.010

Dai, Y., Li, J., Li, J., Yu, L., Dai, G., Hu, A., et al. (2002). Effects of rare earth compounds on growth and apoptosis of leukemic cell lines. In vitro Cell Dev. Biol. Anim. 38, 373-375. doi: 10.1290/1071-2690(2002)038<0373:EORECO >2. $0 . \mathrm{CO} ; 2$

Ding, Y. F., Wen, C., Hodgson, P., and Li, Y. C. (2014). Effects of alloying elements on the corrosion behavior and biocompatibility of biodegradable magnesium alloys: a review. J. Mater. Chem. B 2, 1912-1933. doi: 10.1039/C3TB2 $1746 \mathrm{~A}$

Du, Y. Z., Qiao, X. G., Zheng, M. Y., Wu, K., and Xu, S. W. (2015). The microstructure, texture and mechanical properties of extruded Mg-5.3Zn-0.2Ca-0.5Ce (wt\%) alloy. Mater. Sci. Eng. A 620, 164-171. doi: 10.1016/j.msea.2014.10.028

Ersoy, H., and Rybicki, F. J. (2007). Biochemical safety profiles of gadoliniumbased extracellular contrast agents and nephrogenic systemic fibrosis. J. Magn. Reson. 26, 1190-1197. doi: 10.1002/jmri.21135

Feyerabend, F., Fischer, J., Holtz, J., Witte, F., Willumeit, R., Drucker, H., et al. (2010). Evaluation of short-term effects of rare earth and other elements used in magnesium alloys on primary cells and cell lines. Acta Biomater. 6, 1834-1842. doi: 10.1016/j.actbio.2009.09.024

Gu, X. N., Li, N., Zheng, Y. F., and Ruan, L. (2011). In vitro degradation performance and biological response of a Mg-Zn-Zr alloy. Mater. Sci. Eng. B 176, 1778-1784. doi: 10.1016/j.mseb.2011.05.032

Gui, Z. Z., Kang, Z. X., and Li, Y. Y. (2016). Mechanical and corrosion properties of Mg-Gd-Zn-Zr-Mn biodegradable alloy by hot extrusion. J. Alloys Compd. 685, 222-230. doi: 10.1016/j.jallcom.2016.05.241

Hermawan, H., Dubé, D., and Mantovani, D. (2010). Developments in metallic biodegradable stents. Acta Biomater. 6, 1693-1697. doi: 10.1016/j.actbio.2009.10.006

Heublein, B., Rohde, R., Kaese, V., Niemeyer, M., Hartung, W., and Haverich, A. (2003). Biocorrosion of magnesium alloys: a new principle in cardiovascular implant technology. Heart 89, 651-656. doi: 10.1136/heart.89. 6.651

Homma, T., Mendis, C. L., Hono, K., and Kamado, S. (2010). Effect of Zr addition on the mechanical properties of as-extruded $\mathrm{Mg}-\mathrm{Zn}$-Ca-Zr alloys. Mater. Sci. Eng. A 527, 2356-2362. doi: 10.1016/j.msea.2009.12.024

Hou, X. L., Cao, Z. Y., Wang, L. D., Xu, S. W., Kamado, S., and Wang, L. M. (2011). Microstructure and mechanical properties of extruded Mg-8Gd-2Y0.3Zn-0.6Zr alloy. Mater. Sci. Eng. A 528, 7805-7810. doi: 10.1016/j.msea.2011. 06.034

Huang, K., and Log, R. E. (2016). A review of dynamic recrystallization phenomena in metallic materials. Mater. Des. 111, 548-574. doi: 10.1016/j.matdes.2016.09.012

Jafari, S., Raman, P. K. S., and Davies, C. H. J. (2015). Corrosion fatigue of a magnesium alloy in modified simulated body fluid. Eng. Fract. Mech. 137, 2-11. doi: 10.1016/j.engfracmech.2014.07.007

Jamesh, M. I., Wu, G., Zhao, Y., Mckenzie, D. R., Bilek, M. M. M., and Chu, P. K. (2014). Effects of zirconium and oxygen plasma ion implantation on the corrosion behavior of ZK60 Mg alloy in simulated body fluids. Corros. Sci. 82, 7-26. doi: 10.1016/j.corsci.2013.11.044

Jeong, Y. S., and Kim, W. J. (2014). Enhancement of mechanical properties and corrosion resistance of $\mathrm{Mg}$-Ca alloys through microstructural refinement by indirect extrusion. Corros. Sci. 82, 392-403. doi: 10.1016/j.corsci.2014. 01.041

Kostova, I., Momekov, G., and Stancheva, P. (2007). New samarium(iii), gadolinium(iii), and dysprosium(iii) complexes of coumarin-3carboxylic acid as antiproliferative agents. Met. Based Drugs 2007:15925. doi: $10.1155 / 2007 / 15925$
Luo, J., Yan, H., Chen, R. S., and Han, E. H. (2014). Effects of Gd concentration on microstructure, texture and tensile properties of $\mathrm{Mg}-\mathrm{Zn}$ Gd alloys subjected to large strain hot rolling. Mater. Sci. Eng. A 614, 88-95. doi: 10.1016/j.msea.2014.06.110

Magda, D., and Miller, R. A. (2006). Motexafin gadolinium: a novel redox active drug for cancer therapy. Semin. Cancer Biol. 16, 466-476. doi: 10.1016/j.semcancer.2006.09.002

Mareci, D., Bolat, G., Izquierdo, J., Crimu, C., Munteanu, C., Antoniac, I., et al. (2016). Electrochemical characteristics of bioresorbable binary $\mathrm{MgCa}$ alloys in Ringer's solution: revealing the impact of local $\mathrm{pH}$ distributions during invitro dissolution. Mater. Sci. Eng. C 60, 402-410. doi: 10.1016/j.msec.2015. 11.069

Nagels, J., Stokdijk, M., and Rozing, P. M. (2003). Stress shielding and bone resorption in shoulder arthroplasty. J. Shoulder Elbow Surg. 12, 35-39. doi: $10.1067 / \mathrm{mse} .2003 .22$

Robson, J. D., Henry, D. T., and Davis, B. (2009). Particle effects on recrystallization in magnesium-manganese alloys: particles-stimulated nucleation. Acta Mater. 57, 2739-2747. doi: 10.1016/j.actamat.2009. 02.032

Rosalbino, F., Negri, S. D., Saccone, A., Angelini, E., and Delfino, S. (2010). Bio-corrosion characterization of $\mathrm{Mg}-\mathrm{Zn}-\mathrm{X}(\mathrm{X}=\mathrm{Ca}, \mathrm{Mn}, \mathrm{Si})$ alloys for biomedical applications. J. Mater. Sci. Mater Med. 21, 1091-1098. doi: 10.1007/s10856-009-3956-1

Seitz, J. M., Lucas, A., and Kirschner, M. (2016). Magnesium-based compression screws: a novelty in the clinical use of implants. J. Met. 68, 1177-1181. doi: 10.1007/s11837-015-1773-1

Shi, Z. M., Liu, M., and Atrens, A. (2010). Measurement of the corrosion rate of magnesium alloys using tafel extrapolation. Corros. Sci. 52, 579-588. doi: 10.1016/j.corsci.2009.10.016

Song, G. L., and StJohn, D. (2002). The effect of zirconium grain refinement on the corrosion behaviour of magnesium-rare earth alloy MEZ. J. Light Mater. 2, 1-16. doi: 10.1016/S1471-5317(02)00008-1

Srinivasan, A., Huang, Y., Mendis, C. L., Blawert, C., Kainer, K. U., and Hort, N. (2014). Investigations on microstructures, mechanical and corrosion properties of Mg-Gd-Zn alloy. Mater. Sci. Eng. A 595, 224-234. doi: 10.1016/j.msea.2013.12.016

Staiger, M. P., Pietak, A. M., Huadmai, J., and Dias, G. (2006). Magnesium and its alloys as orthopedic biomaterials: a review. Biomaterials 27, 1728-1734. doi: 10.1016/j.biomaterials.2005.10.003

Sun, H. F., Li, C. J., and Fang, W. B. (2016). Evolution of microstructure and mechanical properties of $\mathrm{Mg}-3.0 \mathrm{Zn}-0.2 \mathrm{Ca}-0.5 \mathrm{Y}$ alloy by extrusion at various temperatures. J. Mater. Res. 229, 633-640. doi: 10.1016/j.jmatprotec.2015.10.021

Wang, Y. S., Tan, M. J., Pang, J., Wang, Z., and Jarfors, A. W. E. (2012). In vitro corrosion behaviors of $\mathrm{Mg} 67 \mathrm{Zn} 28 \mathrm{Ca} 5$ alloy: from amorphous to crystalline. Mater. Chem. Phys. 134, 1079-1087. doi: 10.1016/j.matchemphys.2012. 03.116

Witte, F. (2010). The history of biodegradable magnesium implants: a review. Acta Biomater. 6, 1680-1692. doi: 10.1016/j.actbio.2010. 02.028

Witte, F., Fischer, J., Nellesen, J., Crostack, H. A., Kaese, V., Pisch, A., et al. (2006). In vitro and in vivo corrosion measurements of magnesium alloys. Biomaterials 27, 1013-1018. doi: 10.1016/j.biomaterials.2005. 07.037

Xu, C., Zheng, M. Y., Wu, K., Wang, E. D., Fan, G. H., Xu, S. W., et al. (2013). Effect of final rolling reduction on the microstructure and mechanical properties of Mg-Gd-Y-Zn-Zr alloy sheets. Mater. Sci. Eng. A 559, 232-240. doi: 10.1016/j.msea.2012.08.089

Zhang, D. X., Yang, X. Y., Sun, H., Li, Y., Wang, J., Zhang, Z. R., et al. (2015). Dynamic recrystallization behaviors and the resultant mechanical properties of a $\mathrm{Mg}-\mathrm{Y}-\mathrm{Nd}-\mathrm{Zr}$ alloy during hot compression after aging. Mater. Sci. Eng. A 640, 51-60. doi: 10.1016/j.msea.2015. 05.076

Zhang, X. B., Ba, Z. X., Wang, Z. Z., and Xue, Y. J. (2016). Microstructures and corrosion behavior of biodegradable Mg-6Gd-xZn- $0.4 \mathrm{Zr}$ alloys with and without long period stacking ordered structure. Corros. Sci. 105, 68-77. doi: 10.1016/j.corsci.2016.01.004 
Zhang, X. B., Yuan, G. Y., and Wang, Z. Z. (2012a). Mechanical properties and biocorrosion resistance of $\mathrm{Mg}-\mathrm{Nd}-\mathrm{Zn}-\mathrm{Zr}$ alloy improved by cyclic extrusion and compression. Mater. Lett. 74, 128-131. doi: 10.1016/j.matlet.2012.01.086

Zhang, X. B., Yuan, G. Y., Mao, L., Niu, J. L., and Ding, W. J. (2012b). Biocorrosion properties of as-extruded $\mathrm{Mg}-\mathrm{Nd}-\mathrm{Zn}-\mathrm{Zr}$ alloy compared with commercial AZ31 and WE43 alloys. Mater Lett. 66, 209-211. doi: 10.1016/j.matlet.2011.08.079

Zhang, X. B., Yuan, G. Y., Mao, L., Niu, J. L., Fu, P. H., and Ding, W. J. (2012c). Effects of extrusion and heat treatment on the mechanical properties and biocorrosion behaviors of a Mg-Nd-Zn-Zr alloy. J. Mech. Behav. Biomed. Mater. 7, 77-86. doi: 10.1016/j.jmbbm.2011.05.026
Conflict of Interest Statement: The authors declare that the research was conducted in the absence of any commercial or financial relationships that could be construed as a potential conflict of interest.

Copyright (c) 2018 Yao, Wen, Xiong, Lu and Huttula. This is an open-access article distributed under the terms of the Creative Commons Attribution License (CC $B Y)$. The use, distribution or reproduction in other forums is permitted, provided the original author(s) and the copyright owner are credited and that the original publication in this journal is cited, in accordance with accepted academic practice. No use, distribution or reproduction is permitted which does not comply with these terms. 